研

究

異方性微粉末成形体のHDDR 処理により作製したサブミクロン結晶 $\mathrm{Nd}-\mathrm{Fe}-\mathrm{B}$ 系異方性バルク磁石の組織と磁気特性

\author{
野澤 宣介，西内 武司，広沢哲 \\ 日立金属侏) NEOMAX カンパニー磁性材料研究所，广 618-0013 大阪府三島郡島本町江川 2-15-17.
}

\title{
Microstructure and Magnetic Properties of Submicron-grained Nd-Fe-B Anisotropic Bulk Permanent Magnets Prepared from Compressed Aligned Fine Powder via Hydrogenation-Disproportionation-Desorption-Recombination
}

\author{
Noriyuki Nozawa, Takeshi Nishiuchi and Satoshi Hirosawa \\ Magnetic Materials Research Laboratory, NEOMAX Company, Hitachi Metals, Ltd., 2-15-17 Egawa, Shimamoto-cho, Mishima-gun, \\ Osaka 618-0013, Japan.
}

Received August 27, 2009

\section{SYNOPSIS}

We applied Hydrogenation-Disproportionation-Desorption-Recombination (HDDR) treatment on compacts of fine powder of $\mathrm{Nd}-\mathrm{Fe}-\mathrm{B}$-based alloys to obtain porous, submicron-grained bulk permanent magnets. The crystallographic orientation of the $\mathrm{Nd}_{2} \mathrm{Fe}_{14} \mathrm{~B}$ particles was maintained in the porous magnets, which could be further densified to the full density by hot pressing. Significant improvements over conventional HDDR-processed magnets were observed in the squareness of demagnetization curves for the full-density bulk magnets.

KEY WORDS

$\mathrm{Nd}-\mathrm{Fe}-\mathrm{B}, \mathrm{HDDR}$, Fine crystal, Porous magnet, Hot pressing

\section{1 緒言}

Hydrogenation-Dispropotionation-Desorption-Recombination (HDDR) 法は，水素ガスが関与する反応により結晶方位の 揃った微細結晶を得る熱処理方法として, Nd-Fe-B系の異方 性ボンド磁石用粉末の製造方法に適用されている ${ }^{1,2)}$.

$\mathrm{Nd}_{2} \mathrm{Fe}_{14} \mathrm{~B}$ 相を主相とする $\mathrm{Nd}-\mathrm{Fe}-\mathrm{B}$ 系合金では，合金を 700 $\sim 900^{\circ} \mathrm{C}$ の高温で水素ガス䨌囲気中に保持すると水素化, 相 分離し (“Hydrogenation-Dispropotionation (HD) 反応”), $\mathrm{NdH}_{2}$, $\alpha-\mathrm{Fe}, \mathrm{Fe}_{2} \mathrm{~B}$ の 3 相の不均化組織となる。その後, 高温下で減 圧 (低水素分圧) 䨌囲気にすると合金から水素ガスが排出さ れ, $\mathrm{Nd}_{2} \mathrm{Fe}_{14} \mathrm{~B}$ 相に再結合される ("Desorption-Recombination (DR) 反応”). また Nd-Fe-B系合金の HDDR 処理では Co な゙ の添加や, 水素分圧の制御によって HD 反応を緩慢に行うこ とにより, 再結合した $\mathrm{Nd}_{2} \mathrm{Fe}_{14} \mathrm{~B}$ 相の容易磁化軸の方位が処理 前合金の容易磁化軸の方位をある程度引き継ぎ, 異方性磁石 が得られることが知られている ${ }^{1,3)}$.

しかし HDDR 法により作製されたボンド磁石用粉末 (“HDDR 磁粉”) は, 減磁曲線の角形性が悪く不可逆熱減磁が 大きいため, 耐熱性を要求される用途に使用しづらいという 問題がある. 槙ら ${ }^{4)}$ は HDDR 磁粉に保磁力のばらつきが存在
し，それが角形性の悪化の一因であることを指摘しており， このことからHDDR磁粉を構成する個々の粒子間, あるいは 単一の粒子内に保磁力のばらつきが存在していることが示唆 される. 保磁力のばらつきは, 例えば主相の結晶粒径や, 保 磁力に影響を及ぼすと報告されている粒界相 5 (6)などの組織が 均質でないことを示している.一般的にボンド磁石に用いら れる異方性のHDDR磁粉は, 成形性を考慮して原料粉末の粒 子径を $10 \mu \mathrm{m} \sim 150 \mu \mathrm{m}$ 程度としているが，原料粉末のなかで も例えば $150 \mu \mathrm{m}$ のような比較的大きな粒子径の粒子一個の反 応過程に着目すると, 粒子の表面から内部に向かって反応の 進行の程度に差が生じることが予想される，特にHD 反応時 の不均化組織の形態は, 反応時間とともに大きく変化するこ とが知られ7), その形態にともなって DR反応後の組織も異な ると考えられる.また組織変化との直接的な関連性は明らか になっていないものの, 最終的に得られるHDDR磁粉の保磁 力も $\mathrm{HD}$ 反応の時間にともなって変化することが知られてお り7，このことから特に粒子径の大きな粒子内に保磁力のば らつきが発生し, 角形性が低下していると推測される.

そこで本研究では原料粉末を約 $5 \mu \mathrm{m}$ に微粉砕し, 反応を均 質化させることによる個々の磁粉粒子内の組織および保磁力 
のばらつきの低減と,それに伴う角形性向上の可能性について 検討を行った. またこのとき, 微粉砕した原料粉末を磁界中 成形し $\mathrm{Nd}_{2} \mathrm{Fe}_{14} \mathrm{~B}$ 相の磁化容易軸を揃えておくことで, HDDR 処理時の焼結による異方性バルク磁石の作製を試みた。

\section{2 試料および実験方法}

これまでGutfleischらの報告りやLiらの報告泎により HDDR 磁粉の結晶粒界における $\mathrm{Nd}$ リッチ相の存在が $\mathrm{H}_{\mathrm{cJ}}$ に影響を及 ぼすことが示唆されている. そこで本研究では，原料粉末の 微粉䂶にともなう酸素量増加による Nd リッチ相の減少を考 え, 一般的な HDDR 磁粉と同様の希土類量である $\mathrm{Nd}_{12.8} \mathrm{Fe}_{64.1}$ $\mathrm{Co}_{16} \mathrm{~B}_{6.5} \mathrm{Ga}_{0.5} \mathrm{Zr}_{0.1}$ 組成と, 希土類量を増した $\mathrm{Nd}_{13.7} \mathrm{Fe}_{63.2} \mathrm{Co}_{16} \mathrm{~B}_{6.5}$ $\mathrm{Ga}_{0.5} \mathrm{Zr}_{0.1}$ 組成の 2 種類のストリップキャスト合金を原料合金 として使用した.

はじめに，合金を水素吸蔵崩壞法によって数百 $\mu \mathrm{m}$ に粗粉 砕した後, ジェットミルを用いて中心粉末径 $\mathrm{D}_{50} \doteqdot 5 \mu \mathrm{m}$ とな るように微粉砕した. 微粉砕粉を磁界強度 $1.5 \mathrm{~T}$, プレス圧力 $50 \mathrm{MPa}$ で磁界中成形し，作製した成形体に対しHDDR 処理を 行った. HDDR 処理は “アイソサーマル処理” ${ }^{8)}$ (または “Solid-HDDR 処理” "9) )を適用し, Ar雾囲気中で $840^{\circ} \mathrm{C}$ まで昇温 してから水素雾囲気中で 2 時間, HD 処理した後, 隇圧 Ar中 で1時間，DR処理を行った. ヒートパターンを Fig.1に示す.

得られた試料(バルク体)は, 寸法と単重から密度を求めた. また試料の構成相を X線回折法(XRD)で評価し, 試料の破断 面に打ける微細組織を走查型電子顕微鏡 (SEM) で観察した. さらに試料の磁気特性をBHトレーサーで測定した. 酸素, 窒 素, 炭素を含む試料の成分を高周波誘導結合プラズマ発光分 光分析法(ICP-AES), 非分散赤外線吸収法(NDIR), 熱伝導度 法(TCD) によって分析した.

一方, さらに希土類量の多い $\mathrm{Nd}_{14.2} \mathrm{Fe}_{70.8} \mathrm{Co}_{8} \mathrm{~B}_{6.5} \mathrm{Ga}_{0.5}$ のスト リップキャスト合金を用いた場合は，上記と同様の条件で HDDR 処理まで行い, 得られた試料(バルク体)をホットプレ 又装置にて真空中 $\left(10^{-2} \mathrm{~Pa}\right.$ 以下) で, 温度を $700^{\circ} \mathrm{C}$, 温度保持 時間を 1 時間, プレス圧力を $50 \mathrm{MPa}$ ，プレス方向を磁界中成 形時の配向方向としホットプレスを行った. 試料の寸法と単 重からホットプレス前後の密度を求めた。 またホットプレス 前後の試料の微細組織を電解放射型走査型電子顕微鏡 ( FESEM)で観察した.さららネットプレス前後の試料の磁気特 性をBHトレーサーで測定した。

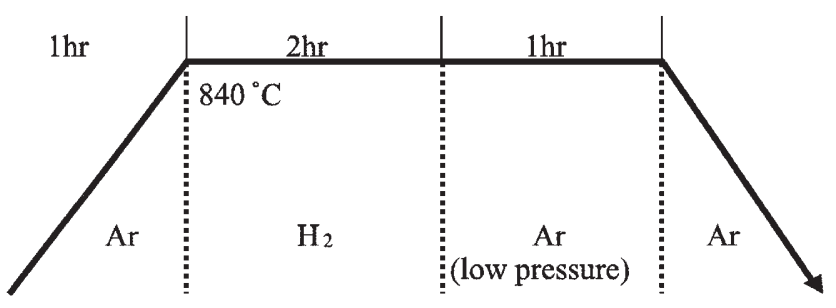

Fig.1 Heat treatment pattern in this work.

\section{3 実験結果および考察}

$3.1 \mathrm{HDDR}$ 処理によって得られた試料の外観と密度変化

Table 1 K HDDR 処理前後での試料の密度を, Fig. 2 K $\mathrm{Nd}_{13.7} \mathrm{Fe}_{63.2} \mathrm{Co}_{16} \mathrm{~B}_{6.5} \mathrm{Ga}_{0.5} \mathrm{Zr}_{0.1}$ 組成で作製した HDDR 処理前の成 形体と HDDR 処理後の試料の外観写真を示す. $840{ }^{\circ} \mathrm{C}$ の HDDR 処理でも焼結による収縮が起こり, 密度が増加するこ とがわかった．また Fig.2の HDDR 処理後試料はサーフェス グラインダーによる研削加工が可能であり，HDDR 処理に よって充分な機械強度を有する焼結体が得られることがわ かった.

3.2 HDDR 処理後の試料の結晶方位

Fig.3に HDDR 処理後の試料のXRD パターンを示す。測定 面は成形時の磁界付与方向に垂直な面とした. $\mathrm{Nd}_{2} \mathrm{Fe}_{14} \mathrm{~B}$ 相に 帰属するピークが観測され，主相である $\mathrm{Nd}_{2} \mathrm{Fe}_{14} \mathrm{~B}$ 相への再結 合が起こっていることがわかる. また, $\mathrm{Nd}_{2} \mathrm{Fe}_{14} \mathrm{~B}$ 相に帰属す るピークのなかでも特に $\mathrm{c}$ 面近傍の面指数ピーク強度が高い ことから, HDDR 処理後も磁界中成形時に配向させた $\mathrm{c}$ 軸 $\left(\mathrm{Nd}_{2} \mathrm{Fe}_{14} \mathrm{~B}\right.$ 相の容易磁化軸)の方位が維持されていることがわ かる.

\subsection{HDDR 処理後の試料の磁気特性}

Fig.4に, BHトレーサーによって測定した試料の減磁曲線 を示す. 希土類組成比の高い $\mathrm{Nd}_{13.7} \mathrm{Fe}_{63.2} \mathrm{Co}_{16} \mathrm{~B}_{6.5} \mathrm{Ga}_{0.5} \mathrm{Zr}_{0.1}$ 組成 は高い固有保磁力 $\left(\mathrm{H}_{\mathrm{cJ}}\right)$ を発現し, 希土類組成比の低い $\mathrm{Nd}_{12.8} \mathrm{Fe}_{64.1} \mathrm{Co}_{16} \mathrm{~B}_{6.5} \mathrm{Ga}_{0.5} \mathrm{Zr}_{0.1}$ 組成は $100 \mathrm{kA} / \mathrm{m}$ 以下の低い $\mathrm{H}_{\mathrm{cj}}$ に留 まった. 高い $\mathrm{H}_{\mathrm{cJ}}$ を発現した $\mathrm{Nd}_{13.7} \mathrm{Fe}_{63.2} \mathrm{Co}_{16} \mathrm{~B}_{6.5} \mathrm{Ga}_{0.5} \mathrm{Zr}_{0.1}$ 組成に おいて, 角形性の指標としている $\mathrm{H}_{\mathrm{k}} / \mathrm{H}_{\mathrm{cJ}}\left(\mathrm{H}_{\mathrm{k}}\right.$ は着磁した試料の 磁化が残留磁束密度 $\left(\mathrm{B}_{\mathrm{r}}\right)$ の $90 \%$ になる減磁界の大きさ) が 0.69 とHDDR法によって作製された磁石として比較的良好な 值を有していた. その要因として, 次の二つが考えられる。一

Table 1 Densities of samples before and after HDDR treatment.

\begin{tabular}{c|c|c}
\hline \multirow{2}{*}{ Composition } & \multicolumn{2}{c}{ Density $\times 10^{3}\left(\mathrm{~kg} / \mathrm{m}^{3}\right)$} \\
\cline { 2 - 3 } & Before HDDR & After HDDR \\
\hline \hline $\mathrm{Nd}_{12.8} \mathrm{Fe}_{64.1} \mathrm{Co}_{16} \mathrm{~B}_{6.5} \mathrm{Ga}_{0.5} \mathrm{Zr}_{0.1}$ & 4.19 & 5.28 \\
\hline $\mathrm{Nd}_{13.7} \mathrm{Fe}_{63.2} \mathrm{Co}_{16} \mathrm{~B}_{6.5} \mathrm{Ga}_{0.5} \mathrm{Zr}_{0.1}$ & 4.19 & 5.46 \\
\hline
\end{tabular}

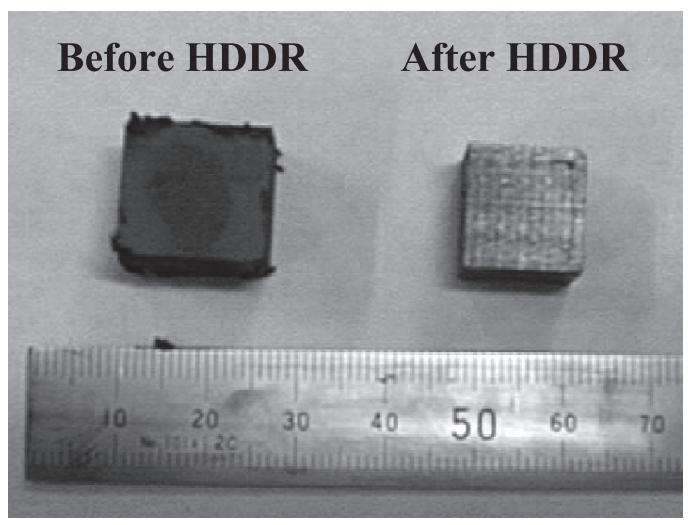

Fig.2 Appearance of the compacts before and after HDDR treatment. 


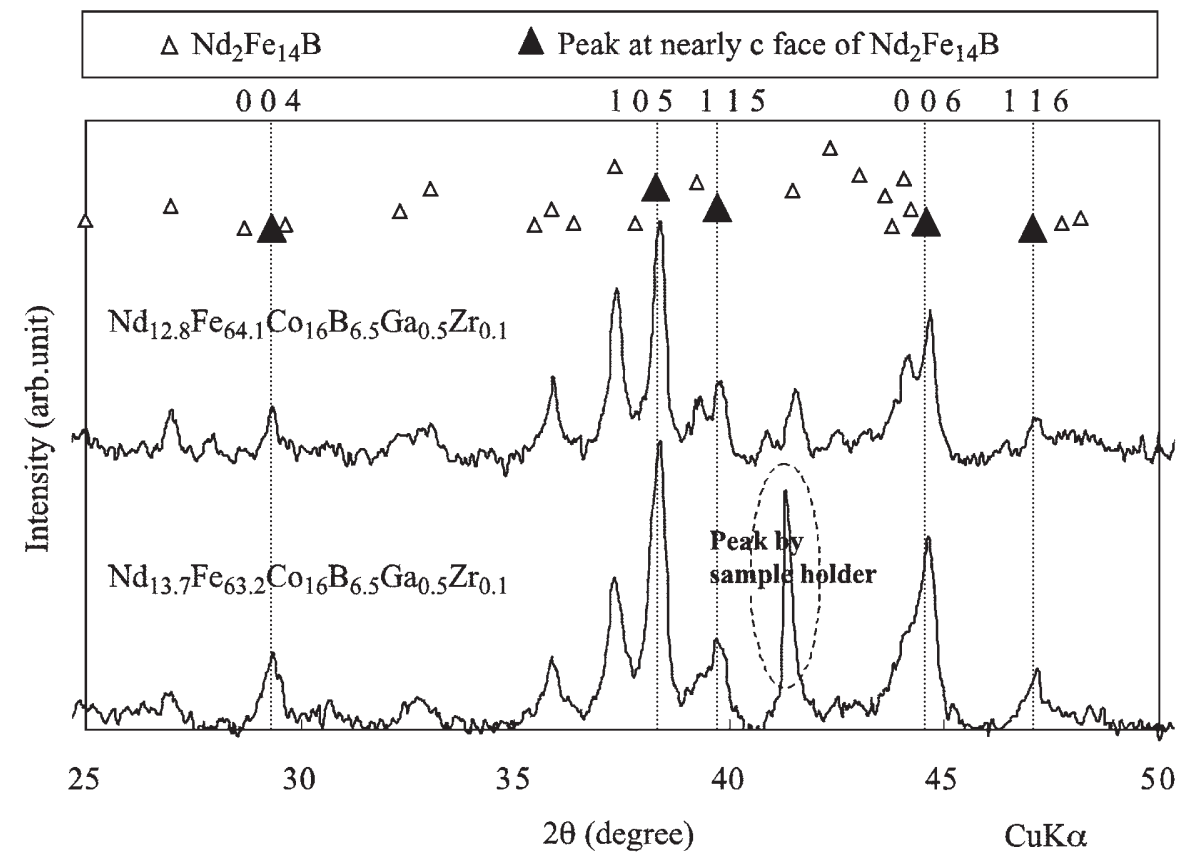

Fig.3 XRD patterns of the compacts after HDDR treatment.

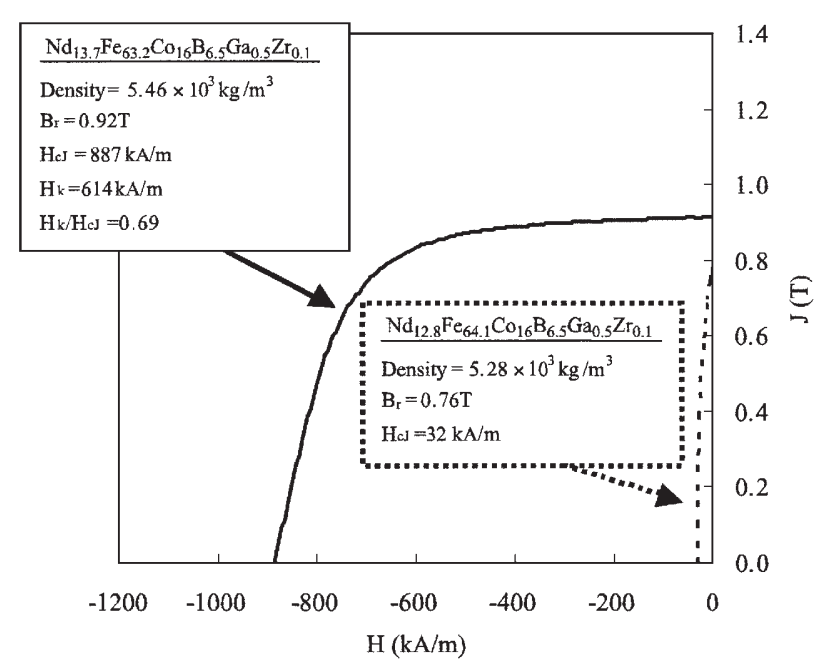

Fig.4 Demagnetization curves of the compacts after HDDR treatment.

つはストリップキャスト合金を原料合金としたことで,一般 的にHDDR磁粉に用いられるインゴットなどに比べ合金中の Ndリッチ相の分布が微細に分散したために, 保磁力に寄与す ると考えられる粒界相の分布等が適正化されたことが考えら れる.もう一つは原料粉末を微粉䂶したことにより, 反応が 均一に進行し, 材料内の組織ばらつきが低減したことが考え られる.

3.4 HDDR 処理後の試料の微細組織

Fig.5に各試料の破断面SEM写真を示す.いずれの試料も， 数 $\mu \mathrm{m}$ の孔が試料全体に見られる多孔質構造であることがわ かる. さらに, 元の原料粉末の粒子同士がネッキングを起こ しているのが確認され，これによって研削加工可能な強度が (a) $\mathrm{Nd}_{12.8} \mathrm{Fe}_{64.1} \mathrm{Co}_{16} \mathrm{~B}_{6.5} \mathrm{Ga}_{0.5} \mathrm{Zr}_{0.1}$

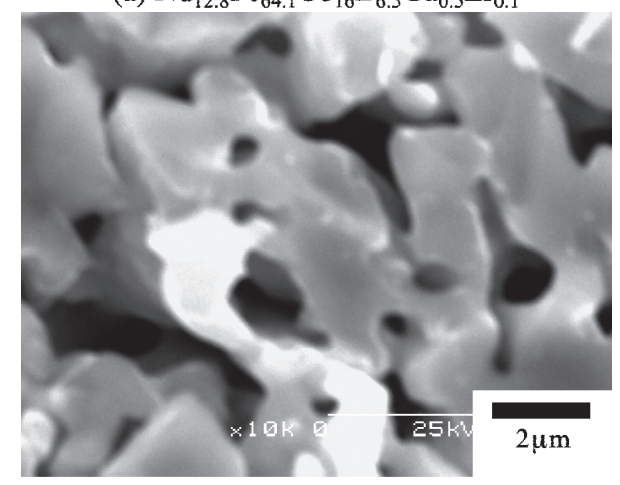

(b) $\mathrm{Nd}_{13.7} \mathrm{Fe}_{63.2} \mathrm{Co}_{16} \mathrm{~B}_{6.5} \mathrm{Ga}_{0.5} \mathrm{Zr}_{0.1}$

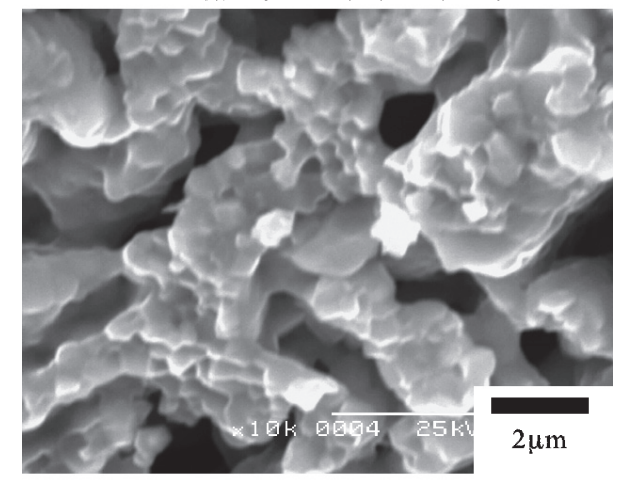

Fig.5 SEM images of the compacts after HDDR treatment.

得られたものと考えられる.

ここで低い $\mathrm{H}_{\mathrm{cl}}$ にとどまった $\mathrm{Nd}_{12.8} \mathrm{Fe}_{64.1} \mathrm{Co}_{16} \mathrm{~B}_{6.5} \mathrm{Ga}_{0.5} \mathrm{Zr}_{0.1}$ の破 断面は, 元の粉末粒子の結晶粒内やネッキングを起こした接 点で破断しているのに対し, 高い $\mathrm{H}_{\mathrm{cJ}}$ を発現した $\mathrm{Nd}_{13.7} \mathrm{Fe}_{63.2}$ $\mathrm{Co}_{16} \mathrm{~B}_{6.5} \mathrm{Ga}_{0.5} \mathrm{Zr}_{0.1}$ の破断面では粒径 $0.3 \sim 0.5 \mu \mathrm{m}$ の微細結晶粒 
が見られ，その結晶粒界で粒界破断していることがわかる. この微細結晶粒の粒径は一般的なHDDR磁粉の結晶粒径と同 等である. 両組成の試料における $H_{C S}$ の差は, この組織の違い によるものと考えられる.

一般的な HDDR 磁粉に用いられる組成と同等である $\mathrm{Nd}_{12.8} \mathrm{Fe}_{64.1} \mathrm{Co}_{16} \mathrm{~B}_{6.5} \mathrm{Ga}_{0.5} \mathrm{Zr}_{0.1}$ で高い $\mathrm{H}_{\mathrm{cJ}}$ が得られない原因として 酸素 $(\mathrm{O})$, 窒素 $(\mathrm{N})$, 炭素 $(\mathrm{C})$ など不純物元素の濃度が増加し たことによるNdリッチ相の隇少が考えられる.特に酸素量は Table 2 に示すように, HDDR 磁粉と同様の粉末径 $(<100 \mu \mathrm{m})$ の試料では酸素量が 0.4 原子\% (at.\%)であるのに対し, 約 $5 \mu \mathrm{m}$ まで微粉砕したことにより酸素量は1.52 at.\%と高い值になっ ている.一般的に Nd-Fe-B系磁石中のO, N, Cはそれぞれ Nd と結合して, 主に $\mathrm{Nd}_{2} \mathrm{O}_{3}, \mathrm{NdN}, \mathrm{Nd}_{2} \mathrm{C}_{3}$ を生成し, 保磁力発現に 寄与するNdリッチ相の割合を低下させることが考えられる. 同様の考え方で微粉砕後の合金粉末の成分分析値から $\mathrm{O}, \mathrm{N}, \mathrm{C}$ を含めた原子濃度を計算し，下記の式を用いて求めた值を “残留 $\mathrm{Nd}$ 量 (Remained $\mathrm{Nd}$ )” $\left(\mathrm{Nd}_{2} \mathrm{Fe}_{14} \mathrm{~B}\right.$ 相を形成する $\mathrm{Nd}$, なら びに不純物である O, N , C と結合する Ndを除いた Nd リッチ 相として存在するNd量)とした. なお，下記の式は簡易的な

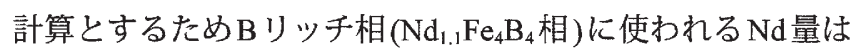
考慮していない。

$$
\begin{array}{r}
{[\text { Remained } \mathrm{Nd}(\text { at.\% })]=[\mathrm{Nd}(\text { at.\% })]} \\
-\frac{2([\mathrm{Fe}(\text { at.\% })]+[\mathrm{Co}(\text { at.\% })])}{14}-\frac{2[\mathrm{O}(\text { at.\% })]}{3} \\
-[\mathrm{N}(\text { at.\% })]-\frac{2[\mathrm{C}(\text { at.\% })]}{3}
\end{array}
$$

一般的な HDDR 磁粉の酸素量 (0.4 at.\%) の場合では, $\mathrm{Nd}_{12.8} \mathrm{Fe}_{64.1} \mathrm{Co}_{16} \mathrm{~B}_{6.5} \mathrm{Ga}_{0.5} \mathrm{Zr}_{0.1}$ は残留 $\mathrm{Nd}$ 量が 0.84 at.\%になるが, 微粉砕して酸素量が増加すると残留 $\mathrm{Nd}$ 量が -0.09 at.\% と負 の值となってしまう.これに対し $\mathrm{Nd}_{13.7} \mathrm{Fe}_{63.2} \mathrm{Co}_{16} \mathrm{~B}_{6.5} \mathrm{Ga}_{0.5} \mathrm{Zr}_{0.1}$ で はあらかじめ $\mathrm{Nd}$ 量を高くしていたことにより 0.71 at.\%と正 の值を維持していた (Table 2).

以上の結果から，残留 $\mathrm{Nd}$ 量が正の值であった $\mathrm{Nd}_{13.7} . \mathrm{Fe}_{63.2}$ $\mathrm{Co}_{16} \mathrm{~B}_{6.5} \mathrm{Ga}_{0.5} \mathrm{Zr}_{0.1}$ のみ粒界相が形成され高い $\mathrm{H}_{\mathrm{cJ}}$ が得られたと 考えられる.

3.5 ホットプレスによるバルク磁石の緻密化

先述したように, Nd-Fe-B合金を微粉砕粉し磁界中成形し た成形体をHDDR処理することで, 多孔質構造を有する微細 結晶バルク磁石が得られることが分かった. 次に高磁束密度 を得るため, この多孔質構造のバルク磁石に対し緻密化を試 みた. 緻密化手段としては, 従来HDDR 磁粉のバルク化手段 として用いられているホットプレス ${ }^{1,10,11)}$ を用いた. なお本検 討ではさらに Nd量を増やした $\mathrm{Nd}_{14.2} \mathrm{Fe}_{70.8} \mathrm{Co}_{8} \mathrm{~B}_{6.5} \mathrm{Ga}_{0.5}$ 組成の合 金を用い, 得られた多孔質構造のバルク磁石についてホット プレスによる緻密化を行った. ホットプレスによって試料密 度は $5.61 \times 10^{3} \mathrm{~kg} / \mathrm{m}^{3}$ から $7.65 \times 10^{3} \mathrm{~kg} / \mathrm{m}^{3}$ となり, 真密度と考 えられる密度まで緻密化した。

次にホットプレス前後での組織変化を電界放射型走査電子 顕微鏡 (FE-SEM) で観察した (Fig.6). 破断面の二次電子 (SE) 像から，ホットプレスを適用することによって，サブミクロ ンサイズの結晶粒径をほぼ維持したまま空孔がなくなり, 緻 密化が十分進行していることが分かる. また，ホットプレス 後の試料において若干, 配向方向に垂直方向に伸びた扁平な 結晶粒が見られた。武下ら ${ }^{1}$ は, HDDR 磁粉から異方性のフ

Table 2 Analyzed contents and calculated "Remained Nd".

\begin{tabular}{c|c|c|c|c|c|c|c}
\hline Composition & $\begin{array}{c}\text { Particle size } \\
(\mu \mathrm{m})\end{array}$ & $\begin{array}{c}\mathrm{Nd} \\
(\text { at.\%) }\end{array}$ & $\begin{array}{c}\mathrm{Fe}+\mathrm{Co} \\
\text { (at.\%) }\end{array}$ & $\begin{array}{c}\mathrm{O} \\
(\text { at.\%) }\end{array}$ & $\begin{array}{c}\mathrm{C} \\
\text { (at.\%) }\end{array}$ & $\begin{array}{c}\mathrm{N} \\
\text { (at.\%) }\end{array}$ & $\begin{array}{c}\text { Remained Nd } \\
\text { (at.\%) }\end{array}$ \\
\hline \multirow{2}{*}{$\mathrm{Nd}_{12.8} \mathrm{Fe}_{64.1} \mathrm{Co}_{16} \mathrm{~B}_{6.5} \mathrm{Ga}_{0.5} \mathrm{Zr}_{0.1}$} & $<100 \mu \mathrm{m}$ & 12.7 & 79.0 & 0.40 & 0.43 & 0.06 & 0.84 \\
\cline { 2 - 9 } & $\fallingdotseq 5 \mu \mathrm{m}$ & 12.4 & 78.5 & 1.52 & 0.34 & 0.05 & -0.09 \\
\hline $\mathrm{Nd}_{13.7} \mathrm{Fe}_{63.2} \mathrm{Co}_{16} \mathrm{~B}_{6.5} \mathrm{Ga}_{0.5} \mathrm{Zr}_{0.1}$ & $\fallingdotseq 5 \mu \mathrm{m}$ & 13.1 & 77.8 & 1.41 & 0.39 & 0.06 & 0.70 \\
\hline
\end{tabular}

(a) Before Hot Pressing

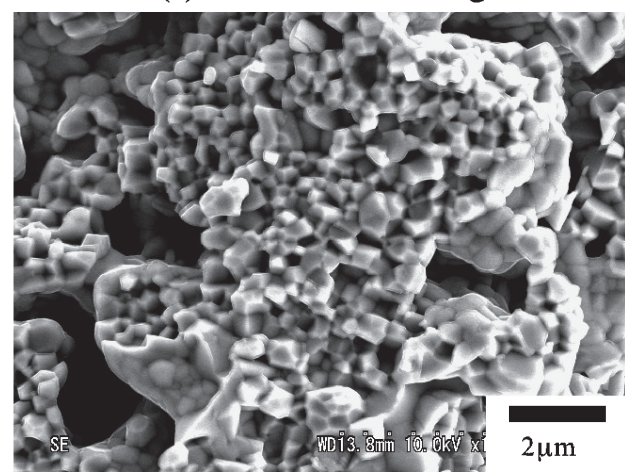

(b) After Hot Pressing

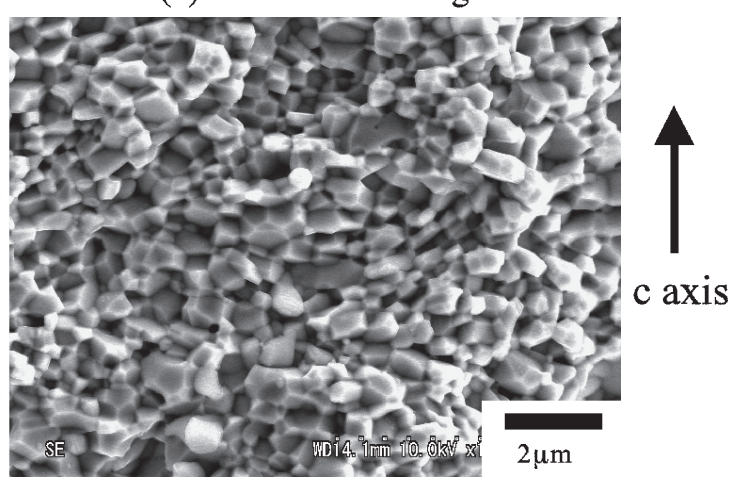

Fig.6 FE-SEM images of the porous bulk magnet and full-density magnet after hot pressing. 
ルデンス磁石を得るためにHDDR磁粉をホットプレスした等 方性の磁石を熱間加工する方法を提案し, McGuiness ${ }^{12)}$ は 実際に熱間加工した異方性磁石を得ている. またGutfleisch ${ }^{13)}$ らはHDDR磁粉のホットプレス体を熱間後方押し出しによっ てラジアル配向させたリング磁石を得て，その磁石に㧊いて 配向方向に垂直に伸ざた扁平な結晶粒を確認しているが, お そらく本検討において確認された扁平な結晶粒はこれらと同 様のものと考元られる. 本検討に扑けるホットプレスはプレ ス方向のみの一軸的な変形であるが, ホットプレス時のプレ ス方向を磁界中成形時の配向方向としたことにより, 緻密化 途中で $\mathrm{Nd}_{2} \mathrm{Fe}_{14} \mathrm{~B}$ 相の $\mathrm{c}$ 軸に垂直な方向への選択的な結晶成長 が起こり, 扁平な結晶粒となったと考えられる.

ホットプレス前後の減磁曲線の変化をFig.7に示す.密度が 向上したことでBr $\mathrm{B}_{\mathrm{r}}$ 向上していることが分かる. またホット プレス後も高い $\mathrm{H}_{\mathrm{c}}$ を維持していることが分かる. さらに $\mathrm{H}_{k} /$ $\mathrm{H}_{\mathrm{CS}}$ が 0.83 とホットプレス前の $0.7 に$ に比べ向上し, HDDR法に よって作製された磁石としては, 非常に優れた角形性を示し た.この理由として二つの要因が考えられる. 一つは, 多孔 質構造によって発生していた磁石内部の局所的な反磁界が, 緻密化によって解消されたことが考えられる．もう一つは， 上述したようにホットプレス中の $\mathrm{Nd}_{2} \mathrm{Fe}_{14} \mathrm{~B}$ 相の $\mathrm{c}$ 面方向への 選択成長により配向性が若干向上したことが考えられる. 実 際に, 配向性の指標としている $\mathrm{B}_{\mathrm{r}} / \mathrm{J}_{\max }\left(\mathrm{J}_{\max }\right.$ は $\mathrm{BH}$ トレーサー 測定時に $1600 \mathrm{kA} / \mathrm{m}$ の磁界を印加した際の, 試料の磁化の最 大測定値)の值がホットプレス前の試料で 0.96 であったのに 対し, ホットプレス後には 0.98 に向上している.

\section{4 ま と め}

$\mathrm{Nd}-\mathrm{Fe}-\mathrm{B}$ 系合金を微粉砕粉し, 磁界中成形した成形体を HDDR 処理することで，以下の知見を得た.

(1) 微粉砕粉の磁界中成形体をHDDR 処理することで, 数 $\mu \mathrm{m}$ の空孔を含む多孔質構造で, 且つ研削加工可能なバルク 体となった.

(2) HDDR 処理後の試料は, 磁界中成形体の磁界配向方向を 維持し異方性磁石であった.

(3) 残留 $\mathrm{Nd}$ 量の值がプラスの組成のバルク磁石は, 結晶粒径 $0.3 \sim 0.5 \mu \mathrm{m}$ の微細結晶粒組織を持ち高い $\mathrm{H}_{\mathrm{cJ}}$ を有してい た. 一方, 残留 $\mathrm{Nd}$ 量の值がマイナスの組成のバルク磁石 は微細結晶組織が見られず低い $\mathrm{H}_{\mathrm{cJ}}$ に留まった.

(4) 多孔質構造のバルク磁石をホットプレスすることで, 結晶 粒径, $\mathrm{H}_{\mathrm{c}}$ を保ちつつ真密度まで緻密化することができた.

(5) 多孔質構造のバルク磁石や, それをホットプレスした高 密度バルク磁石はHDDR 法によって作製された磁石とし ては, 滅磁曲線の角形性に優れていた。

\section{文献}

1) T. Takeshita and R. Nakayama: "Magnetic Properties and Micostructures of the Nd-Fe-B Magnet Powders Produced by HDDR Process-(IV)", Proc. $12^{\text {th }}$ International Workshop on

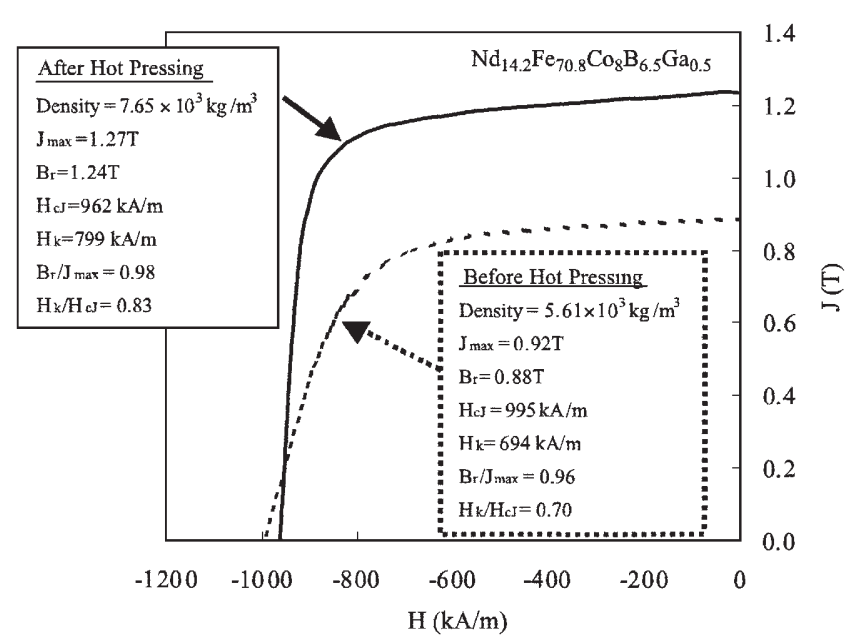

Fig.7 Demagnetization curves of the porous bulk magnet and fulldensity magnet after hot pressing.

Rare-Earth Magnets and Their Applications at Canberra, (1992) 670-681.

2) R. Nakayama and T. Takeshita: "Nd-Fe-B Anisotropic Magnet Powders Produced by the HDDR Process", J. Alloy. Compd., 193(1993)259-261.

3) H. Nakamura, K. Kato, D. Book, S. Sugimoto, M. Okada, and M. Homma: "A Thermodynamic Study of the HDDR Conditions Necessary for Anisotropic Nd-Fe-B Powders", Proc. $15^{\text {th }}$ International Workshop on Rare-Earth Magnets and Their Applications at Dresden, (1998)507-516.

4) T. Maki and S. Hirosawa: "Analysis of Magnetization Behavior of Nd-Fe-B HDDR Magnet by Measuring Recoil Curves", The Papers of Technical Meeting on Magnetics,IEE Japan, (2006) 29-33.

5) O. Gutfleisch, M. Matzinger, J. Fidler, and I.R. Harris: "Characterisation of Solid-HDDR Processed $\mathrm{Nd}_{16} \mathrm{Fe}_{76} \mathrm{~B}_{8}$ Alloys by Means of Electron Microscopy", J. Magn. Magn. Mat., 147 (1995)320-330.

6) W.F. Li, T. Ohkubo, K. Hono, T. Nishiuchi, and S. Hirosawa: "Coercivity Mechanism of Hydrogenation Disproportionation Desorption Recombination Processed Nd-Fe-B Based Magnets", Appl. Phys. Lett., 93(2008)052505.

7) K. Morimoto: "Improvements in Magnetic Properties of Commercial HDDR-Processed Nd-Fe-B Magnet Materials", J. Jpn. Soc. Powder Powder Metallurgy, 52(2005) 171-181.

8) M. Uehara, P. Choi, T. Tomida, H. Tomizawa, S. Hirosawa, and Y. Maehara: "Structural Studies of Some Hydrogen-Treated Materials Related to the HDDR-Process of $\mathrm{Nd}_{2} \mathrm{Fe}_{14} \mathrm{~B}$-Based Alloys", IEEE Trans. Mag., 31(1995)3632-3634.

9) O. Gutfleisch, N. Martinez, M. Verdier, and I. R. Harris: "Phase Transformations during the Disproportionation Stage in the 
Solid HDDR Process in a $\mathrm{Nd}_{16} \mathrm{Fe}_{76} \mathrm{~B}_{8}$ Alloy", J. Alloy. Compd., 215(1994)227-233.

10) K. Mori, R. Nakayama, and K. Morimoto: "Magnetic Properties of Machined Nd-Fe-B HDDR Thin Hot Pressed Magnets", J. Jpn. Soc. Powder Powder Metallurgy, 52(2005)700-705.

11) K. Morimoto, K. Mori, M. Watanabe, E. Niizuma, and R. Nakayama: "Production of Fully Dense Nd-Fe-B Magnets by Hot Preessing Technique Using Semi-Processed HDDR Powders", J. Jpn. Soc. Powder Powder Metallurgy, 47(2000)
1085-1090.

12) P.J. McGuiness, C. Short, A.F. Wilson, and I.R. Harris: "The Production and Characterization of Bonded, Hot-Pressed and Die-Upset HDDR Magnets", J. Alloy. Compd., 184(1992)243255.

13) O. Gutfleisch, A. Kirchner, W. Grünberger, D. Hinz, R. Schäfer, L. Schultz, I.R. Harris, and K.H. Müller: "Backward Extruded NdFeB HDDR Ring Magnets", J. Magn. Magn. Mat., 183 (1998)359-364. 